The Quarterly Journal of Austrian Economics

VOLUME 24 | NO. 1 | 147-165 | SPRING 2021

WWW.QJAE.ORG

\title{
The Unlikely Story of American Regulatory Socialism
}

\author{
James BRougheL
}

JEL Classification: B14, D61, D71, I31, K23, L51

Aвstract: The conventional wisdom has it that US Democrats and those on the American left support incremental steps in the direction of socialism, if not an all-out endorsement of the concept. However, in at least one area-regulation-Republicans and the American political right have also, albeit unwittingly, spread the seeds of socialism not just in Washington, DC, but all across the world. This article reviews the history of federal regulation in the United States, and in particular the arcane, technical history of cost-benefit analysis (CBA), a tool that has become increasingly central in battles over regulation between the Left and the Right. Although right-wing political operatives latched on to CBA in the late 1970s and early 1980s, the tool has a long, complicated history, aspects of which could even be called socialist in nature.

\section{INTRODUCTION}

The conventional wisdom has it that US Democrats and those 1 on the American left endorse a powerful central government,
are skeptical of business, and, perhaps now more than ever, support incremental steps in the direction of socialism, if not an

\footnotetext{
"James Broughel (jbroughel@mercatus.gmu.edu) is a senior research fellow at the Mercatus Center at George Mason University and an adjunct professor of law at the Antonin Scalia Law School. The author is grateful to Kyle Precourt and an anonymous reviewer for helpful suggestions and comments.
} 
all-out endorsement of the concept. But this conventional wisdom is misleading in the sense that the American political right and Republicans have also, albeit unwittingly, spread the seeds of socialism not just in Washington, DC, but all across the world. In at least one area-regulation - this unlikely turn of events seems to be precisely what has happened.

To understand why, one must review the history of federal regulation in the United States, and in particular the arcane, technical history of cost-benefit analysis (CBA), a tool that has become increasingly central in battles over regulation between the Left and the Right. ${ }^{1}$ CBA's origins are in the United States, and although initially controversial, the tool came to be a widely accepted part of regulatory analysis, eventually adopted by European Union member states and countries all over the globe (Lianos, Fazekas, and Karliuk 2016). ${ }^{2}$

CBA was primarily advanced in the US federal government by the political right. Although the tool's roots in federal policy trace back as far as the 1930s, including early use by the Army Corps of Engineers (Tozzi 2011), CBA's place in government wasn't cemented until the 1980s and the Reagan Revolution. In one of his first acts as president, Ronald Reagan signed executive order 12291, which required that executive branch regulatory agencies prepare a cost-benefit analysis for their major regulations. ${ }^{3}$ The order also required that rules and their accompanying analysis undergo a review process overseen by the Office of Information and Regulatory Affairs (OIRA), which had recently been set up to manage paperwork burdens across the government.

\footnotetext{
${ }^{1}$ Throughout this article, I will generalize somewhat with respect to what constitutes a "left-wing" and a "right-wing" perspective. The political orientations of the economists and legal scholars discussed here are not monolithic. However, it is the belief of this author that dividing groups in this way helps to clarify some of the developments that have transpired over the past century with respect to costbenefit analysis.

${ }^{2}$ According to Jacobs, Cordova and Associates, a consulting firm that specializes in regulatory impact analysis, over sixty countries have adopted regulatory impact analysis as a mandatory step in developing new laws. Cost-benefit analysis is a standard part of regulatory impact analysis. See "RIA Resources and News," Jacobs, Cordova \& Associates, accessed October 11, 2020, http://regulatoryreform. com/ria-community/.
}

${ }^{3}$ Exec. Order No. 12291, 46 Fed. Reg. 13193 (Feb. 17, 1981). 
Reagan's executive order stirred controversy at first. Some on the left viewed it as a radical step aimed at deregulation. ${ }^{4}$ Many Democrats wanted the order repealed and OIRA review of regulations suspended. To them, cost-benefit analysis interfered with the discretion of publicly interested regulatory agencies, and OIRA unduly politicized rulemaking by acting as an access point for special interests and political interference from the president. Moreover, those who had pushed hardest for CBA in the late 1970s and early 1980s had come largely from the political right. In particular, the so-called law and economics movement, which consisted of many free-market leaning economists and legal scholars, promoted CBA for its ability to make policy more evidence based and efficient. ${ }^{5}$

However, when a Democrat, Bill Clinton, was eventually elected to the presidency more than a decade after 12291 was signed, he responded in a somewhat unexpected way. Although Clinton did repeal executive order 12291, he replaced it with an order of his own that left intact the core elements of Reagan's order. ${ }^{6}$ Cost-benefit analysis would still be required for the most significant federal regulations, and OIRA review would continue. Minor modifications were made beyond this, but they paled in comparison to the broader shifts in the federal administrative apparatus that Reagan's order helped usher in and which Clinton's order reaffirmed.

Despite this development, many on the left continued to resist the cost-benefit state, even while the analytical tool became institutionalized in American government and even started to be adopted by the fifty states and by other countries. Those on the left were critical, for example, of the CBA practice of assigning dollar values to societal benefits, most notably the practice of putting a dollar value on a human life or on aspects of the environment (Heinzerling and Ackerman 2002). They were also skeptical of discounting, a practice that seemed to treat benefits and costs, including human lives, as akin to money that can be invested in an account and earn interest.

\footnotetext{
${ }^{4}$ Many still oppose OIRA review of regulations in its current form. See, for example, James Goodwin, "The Progressive Case against OIRA," Center for Progressive Reform, Accessed October 11, 2020, https://progressivereform.org/our-work/regulatory-policy/progressive-case-against-oira/. See, also, Steinzor (2012).

${ }^{5}$ For a history and review of the law and economics perspective, see Graham (2008).

${ }^{6}$ Exec. Order No. 12866, 58 Fed. Reg. 190 (1993).
} 
Those on the left who opposed CBA lost these battles over discounting and the value of life, in academic debates as well as in policy settings, as these are now standard parts of cost-benefit analysis. Although the exact discount rate to use in analysis remains controversial, and there are still those scholars who argue that life is priceless or that its value is at least significantly higher than most current estimates used in CBA (Friedman 2020), by the time the Obama administration came into power in the late 2000s, many on the left had moved on from these early controversies, which largely centered around the ethics of cost-benefit analysis.

Instead, left-wing academics began to argue that the American left should embrace cost-benefit analysis, especially by emphasizing the benefits that regulations can bestow upon the public (Revesz and Livermore 2011). The Obama administration harnessed CBA to promote its aggressive regulatory program in a way that previous Democratic presidents had resisted. Harvard law professor and Obama OIRA administrator Cass Sunstein went so far as to dub Obama "the cost-benefit president." 7

By contrast, in recent years, some see former President Trump as having downplayed the significance of CBA, in stark contrast with the Obama years. ${ }^{8}$ The Trump administration even developed an entirely new scheme of regulatory accounting that emphasizes financial costs and cost savings, downplaying nonmarket benefits such as those environmental outcomes so cherished by the Obama administration (Sunstein 2020). In short, roles have reversed in recent years, with the American left emerging as the newest champions of CBA.

\footnotetext{
${ }^{7}$ See "Farewell to the Chief: Our Columnists Assess Obama's Presidency." Bloomberg, Jan. 10, 2017, https://www.bloomberg.com/opinion/articles/2017-01-10/ farewell-to-the-chief-our-columnists-assess-obama-s-presidency

${ }^{8}$ For example, Professor Stuart Shapiro has claimed the Trump administration is waging a "war on analysis," which has "spread to portions of the Republican establishment that have historically been among the advocates for an analytical approach to policy." See Stuart Shapiro, "Trump Still Ignoring Facts, but Numbers Don't Lie," The Hill, Aug. 1, 2017, https://thehill.com/blogs/pundits-blog/the-administration/344798-tell-trump-numbers-dont-lie-how-the-president-ignores. See, also, Stuart Shapiro, "The War on Analysis under the Trump Administration," The Hill, Aug. 13, 2019. Available at: https://thehill.com/blogs/pundits-blog/the-administration/344798-tell-trump-numbers-dont-lie-how-the-president-ignores.
} 


\section{THE DICTATORIAL ORIGINS OF COST- BENEFIT ANALYSIS}

Nothing about the Left's eventual shift toward embracing costbenefit analysis, nor the Right's eventual retreat from it, should be surprising. CBA's academic origins trace back long before right-wing political operatives latched on to the tool in the late 1970s and early 1980s. Aspects of these academic origins could even be called socialist in nature.

As discussed above, crude versions of CBA were used in the federal government as far back as the 1930s. However, CBA's academic foundations had yet to be fully developed at that point, making those early years a kind of analytical Wild West. That began to change around the middle of the twentieth century. One critical moment in CBA's history came in 1950, with the publication of the article "A Difficulty in the Concept of Social Welfare," which was written by a young, up-and-coming economist by the name of Kenneth Arrow (1950). Economists at that time were trying to answer a simple question: What should policy aim to do? Arrow, in a now famous article, was looking for a "social welfare function." He sought a decision rule that could be applied consistently to a broad range of social problems-a logical framework from which one could rank policies (or any other outcomes, for that matter) to determine which best promote societal well-being.

Arrow set certain ground rules in his endeavor. For example, he wanted the decision rule to be based on the preferences of the members of the community being governed (as opposed to being imposed arbitrarily). After establishing a further set of seemingly reasonable restrictions for the social welfare function, he reached the surprising conclusion that the only rule satisfying his criteria is to have the same person in society always decide for everyone. Any other attempts to turn individual preferences into a group decision-making formula will at some point lead to paradoxes, contradictions, or anomalies.

Yet Arrow was clever about how he structured his argument. Rather than prove that the only rational form of collective decision-making is to anoint a dictator, he proactively ruled out that possibility in the assumptions of his theorem. So, what might have been called a "dictatorship theorem" came instead to be known as 
an "impossibility theorem," on the grounds that it seemed to prove that generating a consistent, rational, and broadly applicable social welfare function from the ordinal preferences of the individuals comprising society is impossible.

Right-wing economists in particular interpreted the impossibility theorem as generally ruling out a social welfare function as the normative basis for CBA. Instead, they focused on a simpler welfare measure: economic efficiency. To paraphrase this line of thinking, social welfare is simply too nebulous, too difficult to measure, and too riddled with subjective value judgments. These right-leaning economists latched on to a notion of efficiency that had first been proposed in the late 1930s, known as Kaldor-Hicks efficiency. According to the Kaldor-Hicks criterion, a policy increases efficiency if those who benefit from the policy gain by enough to compensate the people who lose. In theory, everyone could be made at least as well off as (or better than) they were before the policy. The critical catch, however, is that the compensation need not actually happen. Thus, this "potential compensation test" makes no guarantee that a policy will increase present citizens' welfare-only that it will increase aggregate wealth.

To those on the right, focusing on wealth seemed the most scientific way forward, by stripping out most value judgments from the analysis. But this was not the lesson that Arrow himself took from his own work. He was critical of the potential compensation test and of Kaldor-Hicks efficiency for failing to satisfy all of his criteria about what constitutes a rational decision rule (Arrow 1951, 1963). ${ }^{9}$

Arrow never said that constructing a social welfare function is impossible. On the contrary, Arrow based CBA on a mathematical social welfare function. Sometimes he used another name for it, such as a "criterion function" (Arrow and Kurz 1970), or a resource allocation problem that a "social planner" is tasked with solving for society (Arrow et al. 2014). But it was a social welfare function nonetheless. The specific equation he supported for this purpose was (perhaps not surprisingly given his theorem) a single individual's utility function-an individual who looks a lot like a dictator.

Now few, if any, proponents of Arrow equate their support of his ideas with support for actual dictatorship. The "dictator" in question

\footnotetext{
${ }^{9}$ A famous reason why can be found in Scitovszky (1941).
} 
is a benevolent figure whose aim is maximizing the well-being of the members of the community he is charged with planning. In fact, sometimes the dictator is simply viewed as representing the collective welfare of the present generation of citizens. Moreover, the benevolent dictator's well-being increases by making the members of the community better off according to their own values (as measured by their willingness to pay for or accept various benefits and costs).

Still, "dictator" was Arrow's word, and he spent much of his career working out the intricacies of the dictator's welfare function, including detailing the resource allocation problem that the dictator is tasked with solving (Arrow and Debreu 1954). It paid off, too: Arrow won the Nobel Prize in economics in 1972, and the social welfare function he endorsed forms the normative foundation for CBA for many economists on the American left. ${ }^{10}$

\section{TWO FRAMEWORKS, ONLY ONE OF WHICH IS COHERENT}

It should be clear at this point that there is no consensus among economists as to what CBA measures (Broughel 2019). This is a point that economists choose not to advertise too often, but it is a fact nonetheless. On one side, there are those predominantly left-wing economists such as Arrow who want CBA to evaluate some measure of social welfare. For whatever reason, these economists tend to be highly mathematical, viewing the economy as essentially an engineering problem that requires solving. ${ }^{11}$ On the other side there are those, often right-wing and, as it happens, often less mathematically inclined economists and law professors associated with the law and economics movement, who want CBA focused on efficiency and wealth maximization.

\footnotetext{
${ }^{10}$ For a theoretical description of what this article refers to as the "left-wing" approach to cost-benefit analysis, see Drèze and Stern (1987).

${ }^{11}$ Tjalling Koopmans, a colleague of Arrow's at the Cowles Commission, was another important person in this movement. Koopmans codeveloped an economic growth model centered around the same social welfare function that came to underlie cost-benefit analysis. In this way, the left-wing approach to CBA has a connection to economic growth theory that is generally missing from the right-wing, or law and economics, perspective.
} 
Confusing matters further is that if CBA is to measure economic efficiency, there are actually two kinds that economists are concerned with. One refers to an equilibrium situation whereby no one can be made better off without making someone else worse off. This concept, known as Pareto efficiency after the Italian economist Vilfredo Pareto, is well accepted in economics, irrespective of economists' political orientation. However, it is not very useful; there are a nearly infinite number of Pareto-efficient outcomes. How do policymakers know which one to strive for?

The second form of efficiency, alluded to already, emerged in the late 1930s and early 1940s based on the work of economists Nicholas Kaldor and John Hicks (Kaldor 1939; Hicks 1939). Efficiency in this sense refers to maximizing the dollar value of society's scarce resources. Wealth in the Kaldor-Hicks context includes just about anything people are willing to pay for. Thus, it accounts for benefits to human health and the environment, not just goods and services traded in markets.

An important difference between the two forms of efficiency is how they deal with issues of wealth redistribution. Pareto efficiency can be achieved in a competitive market even after substantial redistribution occurs, as the "second fundamental theorem of welfare economics" proves. Many left-leaning economists, including Arrow, see value in Pareto efficiency and incorporate it into their theoretical framework. ${ }^{12}$ Indeed, if a market is more or less competitive, nearly any policy can be expected to produce an efficient result in the Pareto sense; the resulting market equilibrium after people adjust their behavior will eventually be a Pareto-efficient one.

By contrast, the Kaldor-Hicks wealth-maximizing form of efficiency will often show that redistribution destroys some of society's overall wealth and is therefore inefficient. That is because in the process of redistributing, some wealth is typically lost, leading to a reduction in society's total. By and large, left-leaning economists such as Arrow tend to be skeptical of Kaldor-Hicks efficiency, in large part due to its utter indifference to the distribution of wealth. Right-leaning economists tend to view this indifference as a feature and not a bug, either because they tend to see issues of equity and

\footnotetext{
${ }^{12}$ As evidence, Arrow incorporated a Pareto criterion into his impossibility theorem.
} 
distribution as unscientific, or simply because they view equity as something that should be considered separately from efficiency. ${ }^{13}$

This rather unusual state of affairs, whereby left-wing economists base CBA on a benevolent dictator's welfare function, and right-wing economists base CBA on Kaldor-Hicks efficiency and the potential compensation test, is essentially where things have stood for the better part of four decades. In a way, this was a serendipitous outcome. Somehow, despite not even agreeing on what CBA measures, economists settled on two analytical approaches that more or less align in their conclusions in most instances. This is a stunning result. Why not be happy, even grateful, for the current equilibrium?

The problem, in a nutshell, is that the efficiency perspective promoted largely by right-wing academics from the law and economics movement is incoherent. It is true, the two approaches frequently produce similar results, but neither approach actually satisfies the right-wing's policy objectives because neither approach measures Kaldor-Hicks efficiency. Right-wing economists are calling something efficiency that does not meet the definition of efficiency.

If CBA is to measure Kaldor-Hicks efficiency, then it must evaluate wealth in the aggregate, irrespective of its distribution. Specifically, "it treats a dollar as worth the same to everyone" (Posner 2000, 1154). However, modern cost-benefit analysis is not indifferent to distribution in this way.

The reason relates to the social discount rate mentioned earlier: a weight applied to lives and other benefits in the future to determine their present value. Right-wing economists tend to use the discount rate to account for the "opportunity cost of capital" - similar to how a banker uses a discount rate to account for the forgone rate of return cash would earn if left in an account instead of being spent. ${ }^{14}$

${ }^{13}$ One example of this view comes from Posner (2000, 1154-55), which states: "it is possible to set distributive considerations to one side and use the Kaldor-Hicks approach with a good conscience." This is not meant to imply distributive considerations are unimportant, but rather "that distributive justice can be shown to be the proper business of some other branch of government or policy instrument (for example, redistributive taxation and spending)."

${ }^{14}$ The right-wing approach to discounting is known as the "social opportunity cost" approach in the economics literature. The left-wing approach is known as the "social time preference" approach. In general, the right-wing method recommends higher 
It turns out that the right-wing approach to discounting is wrong. CBA is more complicated than ordinary cash flow analysis due to its inclusion of nonmonetary benefits and costs, such as health or lives saved, which do not sit in investment or bank accounts like cash does. In CBA, a discount rate can only be used to account for the opportunity cost of capital under very specific conditions, which don't, as a general matter, hold. (These conditions include specific scenarios such as when all policy benefits are "just like cash" in that they can all be reinvested at the same rates of return forgone due to a policy's financial costs or when a project displaces investment only up until the date a consumption benefit is delivered but no further investment is displaced thereafter.)

The conditions that must be met for a discount rate to account for the opportunity cost of capital represent extremes that are unlikely to be satisfied except when analysis is purely financial. Social regulations - those affecting health, safety, or the environmentconstitute precisely the situations when discounting in the manner right-wing economists do is incorrect, and, as it happens, social regulations are also those rules which are subjected to comprehensive CBA most often. ${ }^{15}$

Not only are right-wing economists not measuring efficiency, but discounting in the manner they do produces calculations with no clear meaning. Social discounting is not consistent with Kaldor-Hicks efficiency, because it by definition reintroduces issues of distribution into analysis by weighting consumption differently depending on who receives it (and when). This violates the standard that one dollar's worth of benefits be treated equally, irrespective of whose pocket it goes in. Thus, the American right pushed CBA into the US federal government without fully understanding the

social discount rates than the left-wing method. For a review of these approaches, see Spackman $(2004)$ and Broughel $(2020 b)$. See also Cowen's $(2007,5)$ explanation of "right-wing" vs. "left-wing" approaches to discounting. Again, I am generalizing somewhat by referring to these groups in political terms. Nonetheless, this framing can be helpful in understanding the nature of these debates.

${ }^{15}$ See, for example, the annual Office of Management and Budget Report to Congress on the Benefits and Costs of Federal Regulations. A disproportionate share of rules with monetized benefits and costs in these reports are social regulations. Reports are available at https://www.whitehouse.gov/omb/information-regulatory-affairs/ reports/\#ORC. 
tool they were championing. Meanwhile, governments around the world quickly followed America's lead by adopting CBA in their own rulemaking procedures.

\section{COST-BENEFIT ANALYSIS IS A DICTATORSHIP OF THE PRESENT}

Unlike the right-wing framework, the left-wing framework is perfectly coherent, at least from a logical point of view. Theirs is the framework of Kenneth Arrow and his followers, where the aim of policymakers is to allocate resources across the economy in a manner consistent with a benevolent social planner's preferences. Left-wing economists also see the social discount rate differently. Rather than account for capital's opportunity cost, it simply reflects the dictator's time preference. ${ }^{16}$

This kind of top-down approach to resource allocation sounds a lot like socialism, wherein the government owns and controls the means of production in society. In this case, a single government planner is tasked with arranging all of the resources in society according to how the present generation of citizens values them most. This method may not meet the textbook definition of socialism, but it is similar in spirit and could easily be viewed as a modern variant. This is the tool that right-wing economists have championed since the early 1980s, have institutionalized in government, and which has now taken hold all over the world, since this is the only coherent rationale for CBA as it is presently conducted.

Because the Kaldor-Hicks approach to CBA is tied up in internal contradictions, right-wing economists unwittingly became advocates for a tool whose true foundations few of them would likely have supported had they fully understood them. Some left-wing economists almost certainly recognized the mistakes made by those on the right and must have been amused, particularly by the role that mathematics seems to have played in confusing their political adversaries. It is not surprising that those on the left would

\footnotetext{
${ }^{16}$ In the left-wing approach to CBA, the opportunity cost of capital is usually either downplayed or ignored altogether, which is a reason for ongoing debate between the left-wing and right-wing approaches to discounting. See Broughel (2020b).
} 
not make much effort to correct the law and economics scholars. After all, those on the right were promoting their method within government and the halls of academia-something unimaginable had the right-wing scholars fully understood CBA's foundations in Arrow's dictatorship theorem or the social welfare function he derived from it.

Careful observers may note that the method by which the social planner allocates resources in Arrow's framework is modeled after the market mechanism, which distributes resources according to how much individuals in society are willing to pay for them. Could Arrow's framework be considered promarket? After all, markets fail in many instances, so perhaps a benevolent social planner could improve upon market outcomes by correcting well-known problems such as externalities or a lack of competition.

There are important differences between Arrow's conception of what policy should aim to do and what the real-world market process is doing. The most notable difference is that the solution to the resource allocation problem Arrow was trying to solve is a static one-that is, it is an optimum from the perspective of the present moment in time only. In a famous paper, Arrow, along with coauthor Gérard Debreu, proved the existence of an optimal allocation of resources in the economy (Arrow and Debreu 1954). But in that framework, time matters only to the extent that present citizens might want to set up contracts for goods and services to be delivered in the future. There is no market that future citizens might participate in to advance their own agendas. The solution is an optimum from the standpoint of present citizens only, not future ones. ${ }^{17}$

This rather strange treatment of time extends to cost-benefit analysis. In a CBA, benefits and costs at future dates get counted, but these benefits and costs are converted into units of present utility through the practice of discounting (Broughel 2020a). In other words, future benefits and costs matter only to the extent they

\footnotetext{
${ }^{17}$ In general equilibrium models of the Arrow-Debreu sort, time is often treated in a manner no different than location, with interest rates representing simple ratios of present and future prices (known as "own rates of return"), rather than a rate at which resources can be transformed into more resources in the future (Cowen 1983). In this sense, general equilibrium models often lack a compelling treatment of capital in addition to time.
} 
impact present utility. It should not be surprising, therefore, that the social welfare function underlying the left-wing CBA framework, a social welfare function known as the discounted utility model, has been labeled a "dictatorship of the present" (Chichilnisky 1996).

Unlike CBA, the market process is not a dictatorship of the present. In real-world markets, entrepreneurs are solving two problems simultaneously. One is to put all of the resources in the right place right now (Arrow and Debreu's concern), but the other is to accumulate as many resources as possible so that there will be more resources available to allocate in the future.

In a typical CBA, benefits are evaluated on the basis of what those who gain are willing to pay for them and costs are based on what those who lose would be willing to accept voluntarily for absorbing the loss. But no money changes hands between these groups when the policy is implemented. There is no requirement, for example, that society's capital stock increase as a result of the policy; indeed the capital stock may well be reduced if present citizens are willing to forgo some investment in order to consume right away. It is therefore easy to imagine a set of policies that pass a cost-benefit test because they meet the approval of the current members of society but that gradually slow the growth rate of the economy.

Entrepreneurs in the market face a different, and dual, test: first, they seek to serve their customers in a manner consistent with those individuals' own values; second, they try to do so in a manner that earns them a profit. A typical CBA focuses only on the first test, ensuring that policies are in line with the preferences of current citizens. But the second test, making a profit, is arguably the more important one. This is what helps ensure that the economy continues to grow, that more resources are available for future allocation, and that economic exchanges do not gradually destroy all of society's wealth.

Without the profit requirement, there could be a situation where a series of policies or other actions all pass a cost-benefit test, because they increase welfare in the present, but nonetheless end up reducing welfare over time. What if everyone today wanted to throw a giant party with all of the wealth that our ancestors bestowed upon us as a bequest? It is easy to see why this might be in line with present preferences, but it is certainly not in the long-run interests of society. 
Casting aside the profit and loss test may leave the present generation content. It is the well-being of people in the future that is in jeopardy when capital is relegated to the sidelines of policy analysis. The oft-overlooked external future benefits of wealth creation are perhaps the most underappreciated aspect of capitalism, and this is precisely the aspect of real-world markets with which modern CBA dispenses.

\section{COST-BENEFIT ANALYSIS AT A CROSSROADS}

Today, CBA stands at a crossroads. It is becoming ever more clear that, as presently conducted, CBA has virtually no connection to the efficiency-maximizing tool that the law and economics movement sold to the public in the early 1980s. It has become a convention among economists to speak about the outputs of CBA as if those outputs revealed something about economic efficiency. But when economists speak in this manner, they are speaking in error. In this way, the language of economists is actually an impediment to progress.

The outputs of CBA are not a statement about wealth, but rather about the utility of an amorphous agent in an economic model. The most charitable way to view this agent is perhaps as representing the collective well-being of present citizens-those whose preferences dictate policy for the time they are alive. But it's hard to see why either those on the left or the right should find this acceptable. The social welfare function underlying CBA is inconsistent with Kaldor-Hicks efficiency, presumably what right-wing economists want. And from a fairness standpoint, presumably the concern of those on the left, the welfare of future generations counts for nothing in this analysis except to the limited extent that it matters to people today. ${ }^{18}$

It is in this analytical void left by mainstream welfare economics that Austrian and public choice economists may have something to offer as a replacement. However, many free market economists have abandoned the cost-benefit enterprise. Some express doubt

\footnotetext{
${ }^{18}$ In the language of economists, the representative agent might value leaving bequests to successors. This could increase the agent's utility today, but successors' utility does not enter into the social welfare function directly.
} 
about the ability to measure cost objectively (e.g., Buchanan 1969; Rothbard 1997). Many express concern about asymmetry in analytical assumptions regarding agents in the market as compared to agents in the government. James Buchanan, for example, expressed deep skepticism of the "benevolent despot" figure that appears so prominently in public economics, and he warned of "political externalities" being bad or worse than market externalities when the assumption of total benevolence is relaxed (Buchanan 1962). Buchanan chastised those who view the role of economist as that of a social engineer tasked with allocating society's scarce resources, and he argued for a more humble and democratic approach to policymaking (Buchanan 1964).

These concerns, raised in the Austrian and public choice literatures, certainly have some validity. These critiques help explain why cost-benefit has been known to be abused for political ends (Zycher 2018) and why regulatory analysis, of which CBA is a part, is sometimes cynically referred to as an "advocacy document" (Elliott 2014; Carrigan and Shapiro 2017). Although it is beyond the scope of this article to address each of these concerns about cost-benefit analysis, it can be said that Austrian economists have something to contribute to current debates surrounding cost-benefit analysis, in large part due to their somewhat unique treatment of the concept of efficiency. Austrian economists tend to view efficiency, and general equilibrium, as an endpoint that entrepreneurial discovery and voluntary, mutually advantageous exchanges move the economy toward (Kirzner 1997). Entrepreneurs identify discrepancies between market prices and resources' opportunity costs, and these "market failures," for lack of a better term, are corrected when entrepreneurs reallocate resources toward higher-valued uses, capturing a profit while doing so. In this way, the market is a process that moves the economy toward an efficient allocation, ${ }^{19}$ although the market process never actually achieves that end.

The law and economics scholars could learn from the Austrian notion of efficiency and perhaps shore up some of the inconsistencies

\footnotetext{
${ }^{19}$ According to Buchanan (1964), "The motivation for individuals to engage in trade, the source of the propensity, is surely that of 'efficiency,' defined in the personal sense of moving from less preferred to more preferred positions, and doing so under mutually acceptable terms."
} 
in their own methods. A first step in this process is likely to involve measuring costs and benefits in dollars, rather than units of a dictator's utility as is the case now. From a technical point of view, it might not be hard to do this. Indeed, the Trump administration's recent experimentation with financial forms of analysis is a clear step in this direction (Broughel 2020a). Such analysis might better approximate economic efficiency than modern CBA, and by extension better account for the actual tradeoffs society confronts when enacting new policies.

None of this is meant to suggest that it would have been better had "the cost-benefit revolution" never happened. Even in its present problematic form, CBA at least forces regulators to have to explain their basic reasoning for programs and regulations that can cost billions of dollars. Analysis requires them to organize the relevant facts and evidence together and to go through an orderly decision-making process. This plausibly makes it more likely that policies achieve their desired outcomes and that some of the worst regulations may never see the light of day as a result of the added scrutiny. Moreover, the institutions that have been set up to produce and review CBA could potentially be reformed in the future to focus on more meaningful measures of welfare.

That said, it will become increasingly obvious to the public and to policymakers that the emperor, in this case CBA, has no clothes-and this will have serious implications for the credibility of economists, as well as the credibility of governments around the world that have chosen to adopt these methods without fully understanding them. Distrust of experts and of expert institutions seems to be at an all-time high. When it comes to cost-benefit analysis and the institutions that support it globally, that lack of trust is entirely deserved.

\section{REFERENCES}

Arrow, Kenneth J. 1950. "A Difficulty in the Concept of Social Welfare." Journal of Political Economy 58, no. 4: 328-46.

. 1951. "Little's Critique of Welfare Economics." American Economic Review 41, no. 5: 923-34. 
_. 1963. Social Choice and Individual Values. 2d ed. New York: John Wiley and Sons.

Arrow, Kenneth J., Maureen L. Cropper, Christian Gollier, Ben Groom, Geoffrey M. Heal, Richard G. Newell, William D. Nordhaus, Robert S. Pindyck, William A. Pizer, Paul R. Portney, Thomas Sterner, Richard S. J. Tol, Martin L. Weitzman. 2014. "Should Governments Use a Declining Discount Rate in Project Analysis?" Review of Environmental Economics and Policy 8, no. 2: 1-19.

Arrow, Kenneth J., and Gerard Debreu. 1954. "Existence of an Equilibrium for a Competitive Economy." Econometrica 22, no. 3: 265-90.

Arrow, Kenneth J., and Mordecai Kurz. 1970. Public Investment, the Rate of Return, and Optimal Fiscal Policy. New York: Resources for the Future Press.

Broughel, James. 2019. “The Mighty Waves of Regulatory Reform: Regulatory Budgets and the Future of Cost-Benefit Analysis." Business, Entrepreneurship, and Tax Law Review 3, no. 2: 206-23.

— . 2020a. "Cost-Benefit Analysis as a Failure to Learn from the Past." Journal of Private Enterprise 35, no. 1: 105-13.

_ . 2020b. "The Seen and the Unseen in Cost-Benefit Analysis." Unpublished manuscript, November 5, 2020. SSRN. https://papers.ssrn.com/ abstract $=3585146$.

Buchanan, James M. 1962. "Politics, Policy, and the Pigovian Margins." Economica 29, no. 113: 17-28.

—. 1964. "What Should Economists Do?" Southern Economic Journal 30, no. 3: 213-22.

- 1969. Cost and Choice: An Inquiry in Economic Theory. Indianapolis, Ind.: Liberty Fund.

Carrigan, Christopher, and Stuart Shapiro. 2017. "What's Wrong with the Back of the Envelope? A Call for Simple (and Timely) Benefit-Cost Analysis." Regulation and Governance 11, no. 2: 203-12.

Chichilnisky, Graciela. 1996. "An Axiomatic Approach to Sustainable Development." Social Choice and Welfare 13, no. 2: 231-57.

Cowen, Tyler. 1983. "The Rate of Return in General Equilibrium-a Critique." Journal of Post Keynesian Economics 5, no. 4: 608-17. 
_ 2007. "Caring about the Distant Future: Why It Matters and What It Means." University of Chicago Law Review 74, no. 1: 5-40.

Drèze, Jean, and Nicholas Stern. 1987. "The Theory of Cost-Benefit Analysis." In vol. 2 of Handbook of Public Economics, edited by Alan J. Auerbach and Martin Feldstein, 909-89. Amsterdam, North-Holland: Elsevier.

Elliott, Donald. 2014. "Rationing Analysis of Job Losses and Gains: An Exercise in Domestic Comparative Law." In Does Regulation Kill Jobs?, edited by Cary Coglianese, Adam M. Finkel, and Christopher Carrigan, 256-71. Philadelphia: University of Pennsylvania Press.

Friedman, Howard S. 2020. Ultimate Price: The Value We Place on Life. Oakland, Calif.: University of California Press.

Graham, John. 2008. "Saving Lives through Administrative Law and Economics." University of Pennsylvania Law Review 157, no. 2: 395-540.

Heinzerling, Lisa, and Frank Ackerman. 2002. "Pricing the Priceless: Cost-Benefit Analysis of Environmental Protection." University of Pennsylvania Law Review 150, no. 5: 1553-84.

Hicks, J. R. 1939. “The Foundations of Welfare Economics." Economic Journal 49, no. 196: 696-712.

Kaldor, Nicholas. 1939. "Welfare Propositions of Economics and Interpersonal Comparisons of Utility." Economic Journal 49, no. 195: 549-52.

Kirzner, Israel M. 1997. "Entrepreneurial Discovery and the Competitive Market Process: An Austrian Approach." Journal of Economic Literature 35, no. 1: 60-85.

Lianos, I., M. Fazekas, and M. Karliuk. 2016. “Cross-National Diffusion in Europe." In Handbook of Regulatory Impact Assessment, edited by C. Radaelli and C. Dunlop, 286-303. Cheltenham, U.K.: Edward Elgar.

Posner, Richard A. 2000. “Cost-Benefit Analysis: Definition, Justification, and Comment on Conference Papers." Journal of Legal Studies 29, no. S2: 1153-77.

Revesz, Richard L., and Michael A. Livermore. 2011. Retaking Rationality: How Cost-Benefit Analysis Can Better Protect the Environment and Our Health. Oxford and New York: Oxford University Press.

Rothbard, Murray N. 1997. "Law, Property Rights, and Air Pollution." In The Logic of Action Two: Applications and Criticism from the Austrian School, 121-70. Cheltenham, U.K.: Edward Elgar. 
Scitovszky, T. de. 1941. "A Note on Welfare Propositions in Economics." Review of Economic Studies 9, no. 1: 77-88.

Spackman, Michael. 2004. "Time Discounting and of the Cost of Capital in Government." Fiscal Studies 25, no. 4: 467-518.

Steinzor, Rena. 2012. “The Case for Abolishing Centralized White House Regulatory Review." Michigan Journal of Environmental and Administrative Law 1, no. 1: 209-85.

Sunstein, Cass R. 2020. “On Neglecting Regulatory Benefits.” Administrative Law Review 72, no. 3: 445-59.

Tozzi, Jim. 2011. “OIRA'S Formative Years: The Historical Record of Centralized Regulatory Review Preceding OIRA's Founding." Administrative Law Review 63: 37-69.

Zycher, Benjamin. 2018. "The Social Cost of Carbon, Greenhouse Gas Policies, and Politicized Benefit/Cost Analysis." Texas AEM Law Review 6, no. 1: 59-76. 